\title{
A new species of Dichanthidium (Hymenoptera, Megachilinae) and first records of the genus in Brazil ${ }^{1}$
}

\author{
Daniele R. Parizotto ${ }^{2,3}$ \& Danúncia Urban ${ }^{2,3}$
}

\begin{abstract}
${ }^{1}$ Contribution number 1806 of the Departamento de Zoologia, Universidade Federal do Paraná.
${ }^{2}$ Laboratório de Biologia Comparada de Hymenoptera, Departamento de Zoologia, Universidade Federal do Paraná, Caixa Postal 19020, 81531-980 Curitiba-PR, Brazil. dparizotto@gmail.com; urban@ufpr.br. ${ }^{3}$ Bolsistas $\mathrm{CNPq}$
\end{abstract}

\begin{abstract}
A new species of Dichanthidium (Hymenoptera, Megachilinae) and first records of the genus in Brazil. The second species of Dichanthidium, D. veredicola sp. nov., is herein described and illustrated from specimens collected in Berizal, Minas Gerais, in southeastern Brazil. Dichanthidium exile Moure is reported for the first time in Brazil, from Corumbá, Mato Grosso do Sul. A diagnosis and a key for the species of the genus are provided.
\end{abstract}

KEYWORDS. Anthidiini; new species; neotropical; taxonomy.

RESUMO. Uma nova espécie de Dichanthidium (Hymenoptera, Megachilinae) e primeiros registros do gênero no Brasil. Uma segunda espécie de Dichanthidium, Dichanthidium veredicola sp. nov., coletada em Berizal, Minas Gerais é descrita e ilustrada. Dichantidium exile Moure é registrado pela primeira vez para o Brasil, com um espécime de Corumbá, Mato Grosso do Sul. São apresentadas uma diagnose e chave para as espécies do gênero.

PALAVRAS-CHAVE. Anthidini; espécie nova; neotropical; taxonomia.

Dichanthidium, an exclusively Neotropical anthidiine genus, was described by Moure (1947a) to encompass a single species from Salta, Argentina, Dichanthidium exile. In another publication in the same year, Moure (1947b) noted that Dichanthidium was distinct from Dianthidium Cockerell and suggested that Dichanthidium could be related to Anthodioctes Holmberg. However, Michener (1948) treated Dichanthidium as a subgenus of Dianthidium and in Michener (2000) Dichanthidium was lumped into the genus Hypanthidioides Moure, along with nine other subgenera.

Dichanthidium is herein treated with the generic status, according to the classification proposed by Urban and Moure (2007), and can be characterized by the following combination of characters: presence of an interalveolar carina; lack of genal and preoccipital carina; pronotal lobe with weakly developed lamella; tegula expanded anterolaterally in a translucent marginal area; scutellum with two basal foveae and a translucent marginal area, exceeding the metanotum; omaulus with short carina; ventral area of mesepisternum and metepisternum with short, plumose and semidecumbent pilosity; base of propodeum with row of pits present only laterally; postspiracular fovea rectangular, marked by trabeculae; arolia present in both sexes; sixth tergum of female with lateral area serrate; female ventral scopa with long, fine and plumose hairs; male with seventh tergum bilobed.

\section{MATERIAL AND METHODS}

Measurements are given in millimeters; total length was measured in lateral view, from head to apex of metasoma; length of forewing was measured at the anterior margin, from the costal sclerite to the wing apex. The type material is deposited in Coleção Entomológica Pe. Jesus Santiago Moure, Departamento de Zoologia, Universidade Federal do Paraná, Curitiba, Brazil (DZUP).

\section{Dichanthidium veredicola sp. nov.}

(Figs. 2-6, 8-9)

Diagnosis. Head with a fine transverse carina connecting the interalveolar carinae; mesoscutum with a reversed J-shaped yellow macula on each side; scutellum black with yellow elongate lateral maculae. Male seventh tergum bilobed, with a weak medial emargination.

\section{Description.}

Holotype male. Length 10.3; length of forewing 8.2; width of second tergum 3.0. Integument of head and mesosoma predominantly black. Head with the following areas yellow: clypeus, except for two lateral basal black maculae; mandibles, except teeth and margins; paraocular bands extending to almost upper angle of compound eyes; supraclypeal area with a yellow spot medially; yellow line on interalveolar carina, exceeding inferior margin of antennal socket; a complete narrow band from postocellar region (Fig. 6) to lower gena, colored by a slightly amber area at vertex. Pronotal lobe with yellow macula; mesoscutum with a reversed J-shaped yellow macula along anterior and lateral edges, slightly ferruginous laterally; discal area of axillae yellow, except for black margins; scutellum with yellow 
elongate lateral maculae. Tegulae ferruginous, translucent anterolaterally. Wing membrane mostly black infumated, darker at base and at costal margin.

Fore and middle legs with coxae, trochanters and femora almost entirely black to dark brown, except for a ferruginous macula on the external surface of femora; tibiae and tarsi ferruginous with black tibial maculae. Hind legs with coxa, trochanter and femur almost entirely black to dark brown, except for yellow maculae on ventral surface of coxa and other yellow maculae on apical surface of femur. Tarsomeres light brown, basitarsus and second tarsomere with ferruginous margin. Basal tergum black with posterior margin ferruginous and with two yellow spots laterally. Spots elongated, widely separated from one another in the middle, and slightly ferruginous dorsally. Second and third terga light ferruginous with yellow lateral bands, bands laterally concave becoming ferruginous medially. Fourth tergum dark, except for one complete band, laterally yellow and dorsally ferruginous, sides as in third tergum. Fifth tergum mostly ferruginous; yellow band wider medially and with lateral margin concave. Sixth tergum mostly black, with a yellow discal macula, smaller than the corresponding macula on fifth tergum (Fig. 9), lateral translucent expansions yellow. Distal tergum with a black basal band; remaining surface yellow, except for a black central macula extending from the middle the posterior margin (Fig. 9). Sterna mostly black, second and third sterna with dark yellow apical band.

Pilosity predominantly yellow, hairs sparse, longer than ocellar diameter; little more conspicuous and longer on paraocular area, apex of the clypeus and sides of terga. On the two basal sterna sparse, slightly denser on third sternum.

Structure. Head densely punctate; mesoscutum with coarser punctures, sparser than those on head; terga with shallow punctures, sparser than those on mesoscutum; propodeal triangle smooth; sixth tergum densely punctate on sides. Interalveolar carinae lamellate, dorsally divergent and with incurved apex; interalveolar carinae joined by a narrow transverse carina which projects forward at supraclypeal area. Sixth tergum with subapical elevations and laminated projected tooth laterally; posterior margin roundly expanded medially and overhanging base of seventh tergum. Distal tergum a little narrower than anterior tergum and with a shallow medial emargination (Fig. 9). Second sternum slightly convex laterally.

Paratype female. Length 7.6; length of forewing 5.6; width of head 2.2; width of second tergum 2.2. Integument mostly black. Head with the following areas yellow: mandibles with basal maculae; clypeus with subapical macula, wider in the middle; paraocular bands almost reaching upper angle of compound eyes, distinctly wider below level of antennal sockets; supraclypeal area with a yellow discal spot; interalveolar carinae with yellow elliptical lines; a complete narrow band from postocellar region (Figs. 2 and 5) to lower gena, colored by a slightly amber area at gena middle (Fig. 4). Pronotal lobe with yellow macula; mesoscutum with a yellow reversed J-shaped macula along anterior and lateral edges, macula interrupted at dorso-lateral angle; axilla and scutellum as in male. Fore and middle legs with coxa and trochanter black, apex of femur to tarsus ferruginous with black maculae. Hind leg black, except for a small ferruginous area at apex of femur, base of tibia and a little yellow subapical macula on femur. Terga mostly black; margin of first to fifth terga translucent ferruginous; tergal bands concave as in male; basal tergum with two yellow spots laterally. Spots widely separated from one another in the middle; second and third terga with yellow bands interrupted medially, distance between maculae as wide as half of scape length; fourth tergum with complete yellow band; fifth tergum almost totally yellow, its sides black; sixth tergum yellow, its sides black. Sterna mostly black. Pilosity and punctures as in male, except for slightly denser punctures at tergal sides.

Type material. Holotype male. BRAZIL, Minas Gerais: "BRASIL, Minas Gerais, Berizal, \Fazenda Veredão, 15.xii.2007, \850m, 15³9'53"S $41^{\circ} 39^{\prime} 56^{\prime}$ 'W, $\backslash$ Grossi, Rafael \& Parizotto cols." (DZUP). Paratype. Female: same data as holotype (DZUP).

Etymology. The specific epithet refers to the place where the new species was collected, the Fazenda Veredão, in northeastern Minas Gerais.

Comments. Although known only from two specimens, it is noteworthy that, in contrast to other Anthidiini, this new species exhibits conspicuous sex dimorphism in body size: the male is larger than the female (10.3 versus $7.6 \mathrm{~mm}$, respectively) and terga are predominantly ferruginous in the male and black in the female. It might be possible, however, that this male specimen represents an unusual color variant, since sex color dimorphism is uncommon within the tribe.

Despite the differences in size and coloration between male and female, there is no doubt that the specimens are from the same species, as they were collected together. Moreover these individuals share diagnostic characters, as the presence of a carina connecting the interalveolar carinae (Figs. 2, 3); the distribution and position of the yellow maculae on head, mesosoma and metasoma. Also, the distribution and size of the integument punctures are very similar in both sexes (Figs. $5,6)$.

\section{Key to Dichanthidium species}

1. Head ferruginous with reduced black areas; supraclypeal area without transverse carina (Fig. 1); mesoscutum with reversed U-shaped ferruginous macula; scutellum ferruginous. Male sixth tergum with a spine-like apical projection in the middle, not overhanging distal tergum and without lateral lamellae; seventh tergum narrower than sixth tergum, bilobed with deep emargination (Fig. 10). Female with distal tergum black ............... D. exile

Head black with yellow areas; supraclypeal area with transverse carina joining interalveolar carinae (Figs. 2, 3); mesoscutum with reversed J-shaped yellow macula laterally; scutellum black with lateral yellow bands (Figs. 5, 6). Male with sixth tergum roundly expanded in the middle, overhanging the base of distal tergum and with lateral lamellae; seventh tergum almost as 

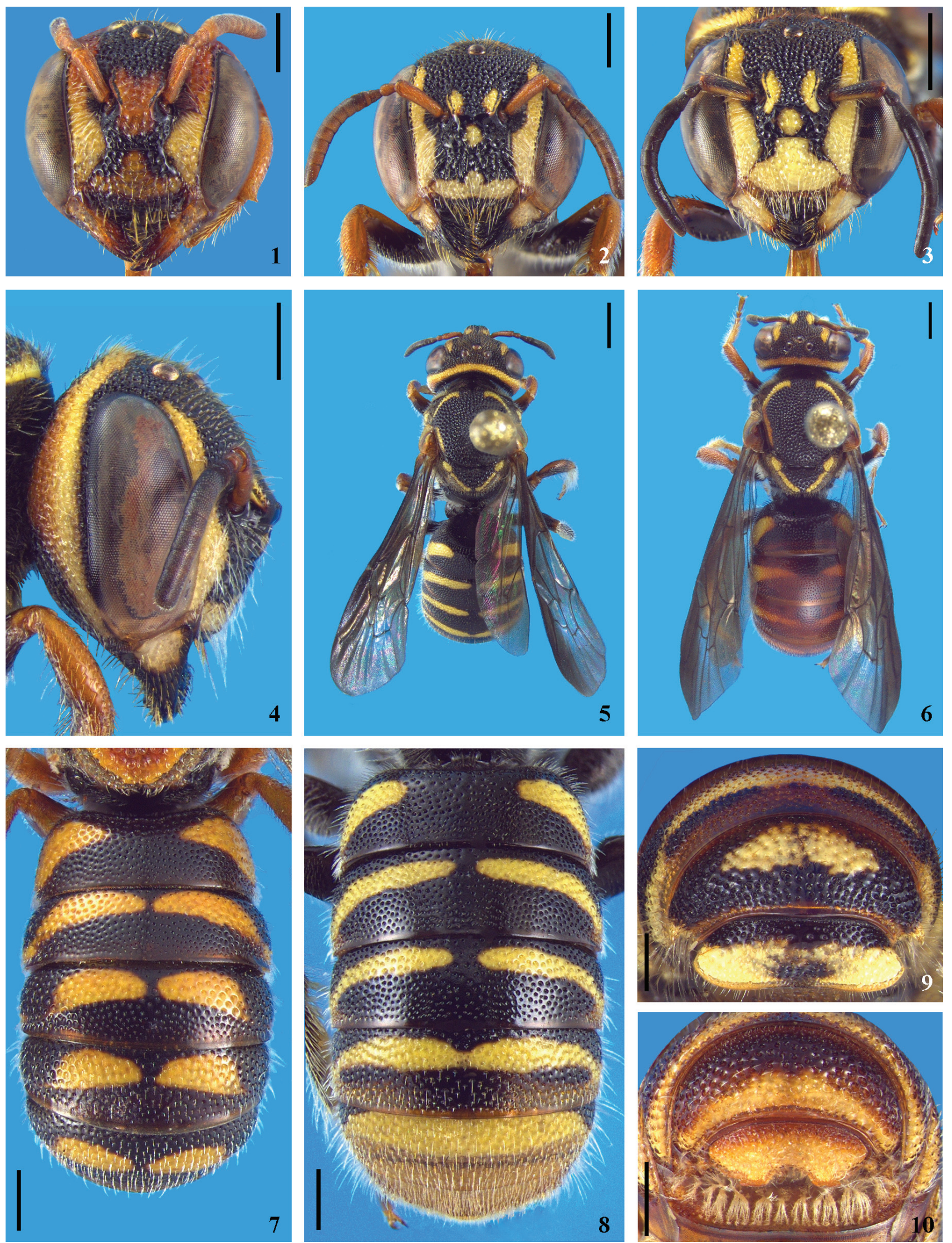

Figs. 1-10. 1, head in front view of female of Dichanthidium exile Moure, 1947; 2-6, Dichanthidium veredicola sp. nov.: 2, head in front view of female; 3 , head in front view of male; 4 , head in lateral view of female; 5 , dorsal view of female; 6 , dorsal view of male; 7 , dorsal view of metasoma of female of Dichanthidium exile; 8, dorsal view of metasoma of female of Dichanthidium veredicola sp. nov.; 9, apex of metasoma of male of Dichanthidium veredicola sp. nov.; 10, apex of metasoma of male of Dichanthidium exile. Scale $=0.5 \mathrm{~mm}$ (Figs. 1-4, 7-10). Scale $=1 \mathrm{~mm}($ Figs. 5, 6). 
wide as sixth tergum, bilobed and with a weak medial emargination (Fig. 9). Female with distal tergum almost entirely yellow $D$. veredicola $\mathbf{s p .}$ nov.

\section{Dichanthidium exile Moure, 1947}

(Figs. 1, 7, 10)

This species, previously known only from Argentina and Bolivia, is now recorded for the first time in Brazil (New country record), as attested by a single male collected at Serra do Urucum, Corumbá, Mato Grosso do Sul in 30-XI-1960 by K. Lenko (DZUP).

Acknowledgements. The authors thank CNPq for supporting this work and Rede Paranaense de Coleções Biológicas (Taxon line) for the photographs used to illustrate this contribution. We would like to thank Grupo N. C. and Mr. Derlane for permission to collect at Fazenda Veredão, in Minas Gerais state. We also thank Paschoal C. Grossi, Eduardo A. B. Almeida and Gabriel A. R. Melo for criticism and suggestions to an earlier version of the manuscript.

\section{REFERENCES}

Moure, J. S. 1947a. Novos agrupamentos genéricos e algumas espécies novas de abelhas sulamericanas. Museu Paranaense, Publicações Avulsas (Curitiba) 3: 1-37.

Moure, J. S. 1947b. Notas sobre algunas abejas de la Provincia de Salta (Hymen. Apoidea). Revista de la Sociedad Entomológica Argentina 13: $218-253$.

Michener, C. D. 1948. The generic classification of the anthidiine bees (Hymenoptera: Megachilidae). American Museum Novitates 1381: $1-29$.

Michener, C. D. 2000. The bees of the world. Baltimore, The Johns Hopkins University Press, xiv +913 p.

Urban, D. \& J. S. Moure. 2007. Anthidiini Ashmead, 1899, p. 875-913. In: J. S. Moure, D. Urban, G. A. R. Melo (Orgs.). Catalogue of Bees (Hymenoptera, Apoidea) in the Neotropical Region. Curitiba, Sociedade Brasileira de Entomologia, xiv +1058 p. 